\title{
Students' Achievement in Basic Electronics: Effects of Scaffolding and Collaborative Instructional Approaches
}

\author{
Bernard Atsumbe ${ }^{1}$, Samuel Owodunni ${ }^{1}$, Emmanuel Raymond ${ }^{1}$, Maxwell Uduafemhe ${ }^{2 *}$ \\ ${ }^{1}$ Department of Industrial and Technology Education, Federal University of Technology, Minna, NIGERIA \\ ${ }^{2}$ Department of Psychometrics, National Examinations Council, Minna, NIGERIA
}

Received 24 January 2018 - Revised 7 March 2018 • Accepted 1 May 2018

\begin{abstract}
This study determined effects of scaffolding and collaborative instructional approaches on students' achievement in Basic Electronics. A quasi-experimental research design was adopted for the study. The performance of 105 Senior Secondary two (SS 2) students in Basic Electronics was obtained after being taught with scaffolding and collaborative instructional approaches using the Basic Electronics Cognitive Achievement Test (BECAT). Data collected were analyzed using mean and ANCOVA. Results revealed that a collaborative instructional approach is more effective in improving student achievement in Basic Electronics than a scaffolding instructional approach. Also, gender had no significant influence on students' achievement in Basic Electronics when taught using scaffolding and collaborative instructional approaches. It was concluded that the collaborative instructional approach is a viable teaching method for improving students' achievement in Basic Electronics. It was recommended that teachers adopt the collaborative instructional approach for teaching Basic Electronics.
\end{abstract}

Keywords: basic electronics, scaffolding instructional approach, collaborative instructional approach, cognitive achievement, gender

\section{INTRODUCTION}

Basic Electronics is one of the vocational courses offered at the upper level of the Nigerian secondary school system. It is a branch of science and technology which deals with the study of the flow and control of electrons in electrical circuits and their behaviour and effects in vacuums, gases, and semiconductors. The objectives of the curriculum are to: (i) support understanding of the basic electronic components in addition to circuits; (ii) lay a good foundation for communication and control systems; (iii) provide a foundation for creativity and technological development in electronics; and (iv) stimulate, develop and enhance entrepreneurial skills in electronics (Nigerian Educational Research and Development Council (NERDC, 2007). In order for these objectives to be realized, teachers of electronics, apart from being versed in the subject matter, needs to be skilled in the selection of appropriate instructional methodologies, as well as effectively put them to use in the classroom. This will greatly determine their instructional success, which is measured by the academic achievements of the students they teach (Ofojebe, 2010).

Essentially, the Nigerian post-primary school is structured into two systems namely; secondary schools and technical colleges. For a student to be admitted into any of the two, s/he must have completed the six years of the primary school as well as the first three years of secondary education (Federal Republic of Nigeria, FRN, 2013). This is why there are two main curricula for secondary education in Nigeria: the conventional secondary school curriculum developed and controlled by the Nigerian Educational Research and Development Council (NERDC), and the technical college curriculum, developed and controlled by the National Board for Technical Education (NBTE). However, there are schools in Nigeria that operate the two curricula. Such schools are science and technical colleges, and they exist in almost every state of the Federal Republic of Nigeria, and are owned by either

(C) 2018 by the authors; licensee Modestum Ltd., UK. This article is an open access article distributed under the terms and conditions of the Creative Commons Attribution License (http://creativecommons.org/licenses/by/4.0/). $\square$ atsumbe@futminna.edu.ng $\boldsymbol{\nabla}$ owoscosam@yahoo.com $\boldsymbol{\nabla}$ emmanuelraymond@futminna.edu.ng 


\section{Contribution of this paper to the literature}

- Scaffolding and collaborative instructional approaches are effective for improving students' cognitive achievement.

- Male students performed better in the Basic Electronics cognitive achievement test than female students.

- The collaborative instructional approach significantly improved student achievement in Basic Electronics over the scaffolding instructional approach.

- There was no significant effect of gender on students' cognitive achievement in Basic Electronics.

- The treatments given to the students did not influence the mean score of one gender over the other in the Basic Electronics Cognitive Achievement Test.

government or private entities. Such schools that operate the two curricula are of particular interest to this study. Literature from examination bodies in Nigeria (National Examinations Council, NECO, 2013) show that the academic achievement of the students in science and technical schools is a source of concern.

In recent times, there have been reports that the academic achievement of students has been below expectation (Animasahun, 2014). According to Ogundola, Abiodun, and Jonathan (2010) this failure to meet expected standards is attributable to the continuous use of unsuitable instructional methodologies (mostly a traditional didactic instructional approach) by teachers. Teachers of courses like Basic Electronics are therefore faced with the challenge of presenting relevant classroom activities that can facilitate conceptual change, allow understanding, and recognize individual differences amongst students. Constructivist-based instructional approaches have these qualities.

The goal of instruction is to make the learner see the world through her/his own eyes, and not through the eyes of anyone else, much less the teacher's. Ertmer and Newby (2013) submitted that, in order to help learners see things based on their own conceptualization, a more learner-centred strategy needs to be adopted. This is the central focus of the constructivist theory of learning. In the constructivist theory of learning, students are assisted to develop and construct their own understanding of the material based upon their own knowledge, beliefs and experiences, in concert with new knowledge presented in the classroom. The theory is a branch of cognitivism since both of them conceive learning as a mental activity. But the constructivist theory of learning differentiates itself from traditional cognitive theories in a number of ways. For instance; most cognitive psychologists think of the mind as a reference tool to the real world; constructivists believe that the mind filters input from the world to produce its own unique reality (Ertmer \& Newby, 2013). This suggests that learners do not transfer knowledge from the real world into their memories but, rather, build personal interpretations of the world based on their experiences and interactions. This makes their interpretation of knowledge open to constant modification. Hence, within the contexts in which knowledge is relevant, new meaning surfaces. Basically, to constructivists, both the learner and environmental factors are crucial, because the interaction between the two creates knowledge. Every action is viewed as an interpretation of the current situation based on an entire history of previous interactions (Husa \& Ron, 2010). Thus, in constructivism, it is impossible to isolate units of information or divide up knowledge domains according to a hierarchical analysis of relationships.

The development of present-day constructivist theory is considered to originate in the work of two early twentieth-century contemporary epistemological theorists, Jean Piaget in 1976 and Lev Vygotsky in 1986, whose cognitive theories of learning were developed as reactions to behaviorism which was the dominant science at the time (Cholewinski, 2009; Wyer Jr., 2014). Behaviourist theory is based upon an objectivist epistemology (Harasim, 2017). Piaget's research focused on the cognitive nature of constructivist learning, and Vygotsky's on its social nature. According to Elander and Cronje (2016), most of the modern teaching and learning techniques we have today are offshoots of objectivism or constructivism. To Cholewinski (2009), this 'revolution' saw constructivism develop as a powerful challenge to behaviourist instructional design and began a paradigm shift in educational design and practices away from 'traditional' methods, which are based upon behaviorist principles, toward those based upon 'constructivist' theories of learning. Constructivist theory of learning first started to receive prominent attention in Japan when educational institutions began to strive toward more constructivist-based instruction in the late 1990s (Cholewinsy, 2009). However, based on available literature, the first time it was used in Nigeria was by Afolabi and Akinbobola in 2009. Afolabi and Akinbobola examined a constructivist problem-based learning technique and the academic achievement of physics students with low ability levels in a Nigerian secondary school (Afolabi \& Akinbobola, 2009). Their findings led to them to recommend the teaching strategy for use in Nigerian classrooms.

The constructivist theory of learning was preferred in this study because it specifies instructional methods that assist learners to actively explore complex topics/ environments. In Basic Electronics, students can be assisted into thinking as an expert user of that domain might think. This is in tandem with McNaught (2014) who noted that "having to cope with an uncertain future calls for a variety of intellectual, interpersonal and personal capabilities". 
Some of these capabilities are critical thinking, creative thinking, self-managed learning, adaptability, problem solving, communication skills, interpersonal skills and groupwork, and computer literacy. McNaught further remarked that "'directed instruction' may be useful in many specific situations but our ultimate goals in education are 'constructivist'". Since, knowledge is not abstract but is linked to the context under study and to the experiences that the participants bring to the context. Essentially, learners are supported to construct their own understandings and then to validate, through social negotiation, these new perspectives. The constructivist theory of learning underpins a number of important approaches, these include: situated learning, concept mapping, collaborative instructional approach, anchored instruction, problem-based learning, cognitive apprenticeship, discovery learning, and scaffolding (Cholewinski, 2009; Jackson, 2006; Jia, 2010; Lai-chong \& Ka-ming, 1996; Rowe, 2006; Wu, Hwang, Su, \& Huang, 2012). This study focused on scaffolding and the collaborative instructional approach.

Scaffolding refer to the process by which a teacher, an instructor or a more knowledgeable peer assists a learner, altering the learning task so the learner can solve problems or accomplish tasks that would ordinarily be impossible for him and to learn from the experience (Reiser, 2004). While McNamara and Brown (2008) defined the collaborative instructional approach as a successful teaching strategy in which small teams, each with students of different levels of ability, use a variety of learning activities to improve their understanding of a subject. If the potentials of scaffolding and collaborative instructional approach are fully utilized, the academic achievement of student of subjects like Basic Electronics could improve.

In line with Bloom's taxonomy of educational objectives and from past question papers of the examination bodies testing students at the secondary level in Nigeria, the type of testing employed for a subject like Basic Electronics, measures both cognitive and psychomotor achievements. However, this study focused only on cognitive achievement. Cognitive achievement reveals how well the educational objectives in the cognitive domain have been realized by a student. It is measured using cognitive achievement tests. When designing achievement tests, whether it is product or process assessment, care should be taken so that there is no gender bias.

Gender refers to state of being male or female. For a long time, gender was listed by researchers as one of the factors that influenced the academic achievement of the child (Abubakar \& Oguguo, 2011; Gupta, Sharma, \& Gupta, 2012). Some researchers believed that boys often out-perform their female counterparts in most subject areas, while some conclude the other way round (Jabor, Machtmes, Kungu, Buntat \& Nordin, 2011; Maliki, Ngban \& Ibu, 2009). Current trends show that the gap that once existed between genders is fast closing (Abubakar \& Bada, 2012). This suggests that females are getting more exposure to educational activities.

\section{Statement of the Problem}

Despite the huge resources expended by Nigerian stakeholders in the educational sector, mass failure in public examinations, especially in science- and technology-related areas which include Basic Electronics, is still being recorded every year (Animasahun, 2014). Recent statistics of academic achievement among students of Basic Electronics over a period of five years (2008-2012) corroborates this. During this period 2,176 candidates sat for examination in the subject in Nigeria. Out of this number, only 771 candidates scored a credit grade or higher, representing a low $35.4 \%$ success rate (NECO, 2013).

It was observed by chief examiners of Basic Electronics (NECO, 2010) that this mass failure could be attributed to teachers' use of unsuitable instructional methodologies, especially traditional teacher-centred methods, in teaching the subject. Hence, teachers need to adopt a learner-centred instructional approach, which will emphasize contextualized and constructive processes, and equip the students with higher-order thinking skills for easy adaptability and flexibility.

Moreover, studies carried out by many researchers have indicated that constructivist approaches are very effective teaching techniques in modern-day teaching. Since constructivist-based approaches are learner-centred, they emphasize contextualized and constructive processes, and equip the students with higher-order thinking skills (Cholewinsky, 2009). Literature also reveals that scaffolding and collaborative instructional approaches are among the most popularly adopted constructivist approaches. Therefore, the problem of this study is, since constructivistbased instructional approaches are more effective than traditional approaches, but have not been used in teaching Basic Electronics, would they be effective for improving student overall achievement in Basic Electronics? Hence, the present study was designed to find out the effects of scaffolding and collaborative instructional approaches on science and technical school students' achievement in Basic Electronics in North-Central Nigeria, with a view of finding out which of the two approaches is more effective.

The specific objectives of the study were to determine the effect of:

1. Scaffolding and collaborative instructional approaches on students' cognitive achievement in Basic Electronics.

2. Gender on students' cognitive achievement in Basic Electronics when taught with scaffolding and collaborative instructional approaches. 


\section{Research Questions}

The following research questions guided the study;

1. What is the effect of scaffolding and collaborative instructional approaches on students' cognitive achievement in Basic Electronics?

2. What is the effect of gender on students' cognitive achievement in Basic Electronics when taught with scaffolding and collaborative instructional approaches?

\section{Hypotheses}

The researchers tested the null hypotheses stated below at 0.05 level of significance:

$\mathbf{H}_{\mathrm{O} 1}$ : There is no significant difference between the mean scores of students in Basic Electronics Cognitive Achievement Test when taught using scaffolding instructional approach and those taught with collaborative instructional approach.

Ho2: There is no significant difference between the mean scores of male and female students when taught with scaffolding and collaborative instructional approaches in the Basic Electronics Cognitive Achievement Test.

$\mathbf{H}_{\mathrm{O} 3}$ : There is no significant interaction effect of treatments given to students and their gender with respect to their mean scores on the Basic Electronics Cognitive Achievement Test.

\section{METHODOLOGY}

The study adopted a quasi-experimental research design; specifically the pre-test post-test non-equivalent control-group experimental design was used. A quasi-experimental design was considered suitable because the study is an experiment where random assignment of subjects to experimental and control groups is not possible, and so intact classes were used (Nworgu, 2006). The researchers randomly assigned intact classes to treatment groups, in order not to interrupt the normal classes of the students and the school time-table.

A sample of 105 (77 males and 28 females) from four schools was drawn using a purposive sampling technique from all the 122 senior secondary school year two (SS II) students of Basic Electronics in the eight science and technical schools offering Basic Electronics in North-Central. This was because few schools offered Basic Electronics and their student population was small. Three types of instruments were used in the study. The first instrument was the lesson plans. Two (2) sets of lesson plans for teaching of the six Basic Electronics topics selected for the study were prepared by the researchers in line with both scaffolding and collaborative instructional approaches (Appendices B and C). Each set contained six lesson plans that were used to teach the students. Each contact lasted for 80 minutes (a double period). The second instrument was an 80-item test blueprint that was developed by the researchers from the lesson plans in line with the six topics that formed the content of this study. The topics were: electrical conduction properties of elements, majority and minority charge carriers, p-n junction diode, diode parameters, electrical rectification and dc power supplies (NERDC Basic Electronics curriculum (2007). This test blueprint was used to generate 80 items (see Table 2). After a face and content validation (details below) was done on this draft Basic Electronics Cognitive Achievement Test (BECAT), it was then subjected to a pilot study at ABI Private Schools, Birnin Kebbi. The psychometric test analysis was done to determine the Difficulty Index and Discrimination Index of each item. According to Okoro (1999), "An item is good if it has Difficulty Index ranging from 20 to 80; Discrimination of 0.20 and above and its entire distractor index a negative decimal". Hence, out of the 80 items generated, a total of 55 items had appropriate difficulty and discrimination indices. From the 55 items that had good difficulty and discrimination indices, 50 items were selected and used for the final version of the BECAT. The third instrument was thus the final BECAT. BECAT has 50, four-option multiple-choice items, generated using the test blue-print drawn on six Basic Electronics topics selected. Appendix A shows a sample of the questions in the BECAT.

The three instruments - lesson plans, test blueprint and BECAT - were validated by three people with Industrial and Technology Education background. One of them was a lecturer of Electrical and Electronics Technology Education drawn from Department of Industrial Technology and Education (ITE), Federal University of Technology, Minna; the second was a teacher of Electronics, with at least five years' experience at the secondary school level in Abuja and the third was an experienced staff of the Department of Examination Development, National Examinations Council, who was a teacher of Basic Electronics before joining the council as a Basic Electronics examination officer. Since the BECAT items are multiple-choice, reliability testing of BECAT was carried out with the use of Kuder-Richardson 20 (K-R 20) and a reliability coefficient of 0.88 was obtained. Data collected were analyzed using mean and ANCOVA at 0.05 level of significance. 
Table 1. Distribution of Schools Used for the Study According to Name of School, Group, Treatment Method and Number of Students

\begin{tabular}{clcc}
\hline S/No. & Name of School & Treatment group & Treatment Method \\
\hline 1 & Federal Science and Technical College, Otukpo & B & Scaffolding \\
\hline 2 & Federal Science and Technical College, Doma & A & Collaborative \\
\hline 3 & Synto Secretariat, Suleija & A & Collaborative \\
\hline 4 & Federal Science and Technical College, Kuta & B & Scaffolding \\
\hline & TOTAL & & 27 \\
\hline
\end{tabular}

\section{Experimental Procedure}

The study took place during the normal school setting. The timetable of each school and lesson duration was followed without alteration. Detailed instructions with lesson plans for the six selected topics were given to the four research assistants during the one-week training that was conducted for them. The training pack included detailed lesson plans on the six Basic Electronics topics for the instructional approach to be undertaken by each research assistant; as well as the procedural steps for implementing the instructional approach on which they were trained. Treatment group A was taught using the Collaborative Instructional Approach. In this treatment group, the research assistants divided the students into group of threes and explained to each group about how they will work together, sharing ideas and solving the given problems as a team. Also, the scoring of assignments was on a group basis. The think-share-pair strategy was used. On the other hand, Treatment group B was taught using the Scaffolding Instructional Approach. In this treatment group, the research assistants simply used series of scaffolds, such as flash cards, visual (pictorial) scaffolds and question cards to facilitate the lessons. Table 1 shows the distribution of schools used for the study according to name of school, group, treatment method and number of students.

The influences of extraneous variables were checked as follows: firstly, the influence of Hawthorne effect was addressed by using each school's regular Basic Electronics teacher. These teachers were grouped into two and trained in isolation of each other. Secondly, the influence of pre-test sensitization was addressed by retrieving all pre-test question papers and by rearranging the post-test questions in such a way that the first question in the pretest became the last in the post-test. Thirdly, the influence of initial group differences was addressed by the use of analysis of covariance (ANCOVA) for the data analysis. Fourthly, the influence subjects' interaction was controlled by the use of intact classes for each treatment group in each school used for the research, so that subjects (students) from one treatment group do not introduce biases in the results by crossing to a treatment group they were not originally assigned to.

In the first week, BECAT was administered to both the Treatment groups A and B. This was followed by a sixweek period of treatment of the two groups. Each lesson lasted for 80 minutes (a double period). At the end of the treatment period, a post-test was administered on both groups with BECAT containing the same questions, but rearranged such that the last item in the pre-test became the first item in the post-test. The scores that were obtained from both groups were compared to determine if there is any significant difference in their cognitive achievement. Therefore, the scores were collected and kept in the custody of the researchers for use in further analyses.

\section{Method of Data Analysis}

The data collected for the study were analysed using mean statistics and analysis of covariance (ANCOVA). Mean statistics was used to answer the two research questions of the study. While the null hypotheses were tested using ANCOVA at 0.05 level of significance. ANCOVA was considered suitable because the study involved two independent variables (teaching methods and gender), a dependent variable (post-test scores) and a covariate (pretest scores). Also, Nworgu (2006) stated that the most appropriate statistical technique for analysing data from a pre-test-post-test control-group design is ANCOVA. 
Table 2. An 80-Item Test Blue Print for Basic Electronics Based on Six Topics

\begin{tabular}{|c|c|c|c|c|c|c|c|c|c|}
\hline \multicolumn{10}{|c|}{ Number of Items in Cognitive level } \\
\hline $\mathrm{S} / \mathrm{Nc}$ & TOPIC & $\%$ & $\mathbf{K}$ & $\mathbf{C}$ & App & Anal & $\mathbf{S}$ & $\mathbf{E}$ & Total \\
\hline 1. & Electrical conduction properties of elements & 10 & - & 1 & 1 & 3 & 2 & 1 & 8 \\
\hline 2. & Majority and minority charge carriers & 15 & - & 1 & 2 & 4 & 3 & 2 & 12 \\
\hline 3. & $\mathrm{P}-\mathrm{N}$ junction diode & 20 & 2 & 2 & 2 & 3 & 4 & 3 & 16 \\
\hline 4. & Diode parameters & 15 & 1 & 1 & 1 & 3 & 4 & 2 & 12 \\
\hline 5. & Electrical rectification & 20 & 1 & 2 & 3 & 4 & 3 & 3 & 16 \\
\hline 6. & DC power supplies & 20 & 1 & 2 & 4 & 3 & 4 & 2 & 16 \\
\hline & TOTAL & 100 & 5 & 9 & 13 & 20 & 20 & 13 & 80 \\
\hline
\end{tabular}

$\mathrm{K}=$ Knowledge, $\mathrm{C}=$ Comprehension, App = Application, Anal = Analysis, $\mathrm{S}=$ Synthesis, $\mathrm{E}=$ Evaluation

Table 3. Pre-test and Post-test Mean Scores of Treatment Groups Taught Basic Electronics with Scaffolding and Collaborative Instructional Approaches in the BECAT

\begin{tabular}{llccccc}
\hline Group & N & Pre-test $\overline{\mathbf{x}}$ & SD & Post-test $\overline{\mathbf{x}}$ & SD & Mean Gain $\overline{\mathbf{x}}$ \\
\hline Group A (CIA) & 52 & 11.19 & 2.61 & 35.60 & 1.14 & 24.41 \\
\hline Group B (SIA) & 53 & 11.25 & 2.63 & 25.51 & 1.45 & 14.26 \\
\hline
\end{tabular}

$\mathrm{CIA}=$ group with Collaborative Instructional Approach, SIA = group with Scaffolding Instructional Approach.

\section{RESULTS}

\section{Research Question 1}

What is the effect of scaffolding and collaborative instructional approaches on students' cognitive achievement in Basic Electronics?

Table 3 shows that Treatment group A (group treated with the Collaborative Instructional Approach) had a pre-test mean score of 11.19 and a standard deviation (SD) of 2.61. Post-test mean score was 35.60 and a standard deviation of 1.14. These yielded a pre-test, post-test mean gain of 24.41. However, Treatment group B, (group treated with the Scaffolding Instructional Approach) had a pre-test mean score of 11.25 and a standard deviation of 2.63. In the same vein, treatment group B had a post-test mean score of 25.51 and a standard deviation of 1.45, giving a pre-test, post-test mean gain of 14.26. With these results, the students in Treatment group A performed better in the cognitive achievement test than the students in Treatment group B. Hence, collaborative instructional approach appears to be more effective than scaffolding instructional approach in Basic Electronics.

\section{Research Question 2}

What is the effect of gender on students' cognitive achievement in Basic Electronics when taught with scaffolding and collaborative instructional approaches?

Table 4 shows that male students taught Basic Electronics using the Scaffolding Instructional Approach had a pre-test mean score of 11.15 and a standard deviation of 2.74 . The post-test mean score was 25.73 and a standard deviation of 1.40. These give a pre-test, post-test mean gain of 14.11. Similarly, their female counterparts taught using the Scaffolding Instructional Approach had a pre-test mean score of 11.62 and a standard deviation of 2.51, a post-test mean score of 24.85 and a standard deviation of 1.46, giving a pre-test, post-test mean gain of 13.23. Also, male students taught Basic Electronics using the Collaborative Instructional Approach had a pre-test mean score of 11.47 and a standard deviation of 2.71, a post-test mean score of 36.00 and a standard deviation of 1.08 giving a pretest, post-test mean gain of 24.53. Their female counterparts taught using the Collaborative Instructional Approach, had a pre-test mean score of 10.43 and a standard deviation of 2.55 and a post-test mean score of 34.50 and a standard deviation of 1.19, giving a pre-test, post-test mean gain of 24.07. From these results, male and female students taught Basic Electronics using the Collaborative Instructional Approach had a higher mean gain than those taught using the Scaffolding Instructional Approach in the BECAT. Also, male students performed better than the females. This could perhaps indicate an effect attributable to gender on the achievement of students taught Basic Electronics. 
Table 4. Pre-test and Post-test Mean Scores of Male and Female Students Taught Basic Electronics with Scaffolding and Collaborative Instructional Approaches in the BECAT

\begin{tabular}{|c|c|c|c|c|c|c|c|c|c|c|c|c|}
\hline \multirow[b]{3}{*}{ Gender } & \multicolumn{6}{|c|}{ Scaffolding Instructional Approach } & \multicolumn{6}{|c|}{ Collaborative Instructional Approach } \\
\hline & \multirow[t]{2}{*}{$\mathbf{N}$} & \multicolumn{2}{|c|}{ Pre-test } & \multicolumn{2}{|c|}{ Post-test } & \multirow{2}{*}{$\begin{array}{c}\text { Gain } \\
\overline{\mathbf{x}}\end{array}$} & \multirow[t]{2}{*}{$\mathbf{N}$} & \multicolumn{2}{|c|}{ Pre-test } & \multicolumn{2}{|c|}{ Post-test } & \multirow{2}{*}{$\begin{array}{c}\text { Gain } \\
\overline{\mathbf{x}} \\
\end{array}$} \\
\hline & & $\overline{\mathbf{x}}$ & SD & $\overline{\mathbf{x}}$ & SD & & & $\overline{\mathbf{x}}$ & SD & $\overline{\mathbf{x}}$ & SD & \\
\hline Male & 40 & 11.15 & 2.74 & 25.73 & 1.40 & 14.11 & 38 & 11.47 & 2.71 & 36.00 & 1.08 & 24.53 \\
\hline Female & 13 & 11.62 & 2.51 & 24.85 & 1.46 & 13.23 & 14 & 10.43 & 2.55 & 34.50 & 1.19 & 24.07 \\
\hline
\end{tabular}

Table 5. Summary of Analysis of Covariance (ANCOVA) for Test of Significance of Three Effects: Treatment, Gender and Interaction on Students' Cognitive Achievement in Basic Electronics

\begin{tabular}{lccccc}
\hline Source & Type III Sum of Squares & Df & Mean Square & F & Sig. \\
\hline Corrected Model & 15764.673 & 4 & 3941.168 & 265.228 & 0.000 \\
\hline Intercept & 276.267 & 1 & 276.267 & 18.592 & 0.000 \\
\hline Pre-test & 200.050 & 1 & 200.050 & 13.463 & 0.000 \\
\hline Gender & 1.188 & 1 & 1.188 & 0.080 & $0.778^{*}$ \\
\hline Treatment & 11915.704 & 1 & 11915.704 & 801.888 & $0.000^{*}$ \\
\hline Gender * Treatment & 1.326 & 1 & 1.326 & 0.089 & 0.766 \\
\hline Error & 1485.955 & 100 & 14.860 & & \\
\hline Total & 74324.000 & 105 & & & \\
\hline Corrected Total & 17250.629 & 104 & & & \\
\hline \multicolumn{7}{l}{ "Significant at sig. of F <.05 } \\
\hline
\end{tabular}

\section{Hypotheses}

Ho1: There is no significant difference between the mean scores of students in the Basic Electronics Cognitive Achievement Test when taught using scaffolding instructional approach and those taught with collaborative instructional approach.

$\mathbf{H}_{\mathrm{O} 2}$ : There is no significant difference between the mean scores of male and female students when taught with scaffolding and collaborative instructional approaches in the Basic Electronics Cognitive Achievement Test.

$\mathbf{H}_{\mathrm{O} 3}$ : There is no significant interaction effect of treatments given to students and their gender with respect to their mean scores on the Basic Electronics Cognitive Achievement Test.

The data in Table 5 shows the F-calculated values for three effects: treatment, gender and interaction on students' cognitive achievement in Basic Electronics. The F-calculated value for treatment is 801.888 with a significance of $\mathrm{F}$ at 0.000 which is less than 0.05 . This result shows that there is a significant difference between the mean scores of students in the Basic Electronics Cognitive Achievement Test when taught using the scaffolding instructional approach and those taught with the collaborative instructional approach. The null-hypothesis one is therefore rejected at 0.05 level of significance. The F-calculated value for gender is 0.080 with a significance of $F$ at 0.778 which is greater than 0.05 . This result shows that there is no significant difference between the mean scores of male and female students when taught with scaffolding and collaborative instructional approaches in Basic Electronics Cognitive Achievement Test. The null-hypothesis two is therefore accepted at 0.05 level of significance. Also, the interaction of treatments and gender has an F-calculated value of 0.089 with significance of $F$ of 0.766 . From this, 0.766 is obviously greater than 0.05 . Hence, there is no significant effect of treatments given to students on their gender with respect to their mean scores on the Basic Electronics Cognitive Achievement Test. The nullhypothesis three is therefore accepted at 0.05 level of significance.

\section{Findings of the Study}

The following were the findings recorded:

1. Scaffolding and collaborative instructional approaches are effective for improving students' cognitive achievement. However, the collaborative instructional approach was more effective than the scaffolding instructional approach.

2. There was an effect of gender on students' cognitive achievement in Basic Electronics.

3. There was a significant difference between the mean scores of students in Basic Electronics Cognitive Achievement Test when taught using the scaffolding instructional approach and those taught with the collaborative instructional approach, in favour of the collaborative instructional approach. 
4. There was no significant effect of gender on students' cognitive achievement in Basic Electronics.

5. There was no significant interaction effect of treatments given to students and their gender with respect to their mean scores on the Basic Electronics Cognitive Achievement Test.

\section{DISCUSSION OF FINDINGS}

The data in Table 3 provides answer to research question one. The finding revealed that scaffolding and collaborative instructional approaches are effective for improving students' cognitive achievement. However, the collaborative instructional approach was more effective than the scaffolding instructional approach. Analysis of covariance was used to test hypothesis one (Table 5). This indicated that there was a significant difference between the mean scores of students in the Basic Electronics Cognitive Achievement Test when taught using the scaffolding instructional approach and those taught with the collaborative instructional approach, in favour of the collaborative instructional approach. This confirmed that the difference between the collaborative instructional approach and the scaffolding instructional approach was statistically significant.

These imply that scaffolding and collaborative instructional approaches are effective for teaching Basic Electronics. However, the collaborative instructional approach is more effective than scaffolding instructional approach. This finding is similar to that of Gokhale (1995) who found that students who participated in a collaborative instructional approach performed significantly better on a critical-thinking test than students who studied individually as in scaffolding. Similarly, Dooly (2008) discovered that, in the collaborative instructional approach, students actively exchange, debate and negotiate ideas within their groups, and this increases the students' interest in learning. Importantly, by engaging in discussion and taking responsibility for their learning, students are encouraged to become critical thinkers. By working in small groups, students tend to learn more of what is being taught and retain the information longer, and also appear more satisfied with their classes. Therefore, the difference observed between the two groups is as a result of the collaborative instructional approach being more effective in improving students' cognitive achievement in Basic Electronics than the scaffolding instructional approach.

The data in Table 4 provides an answer to research question two. The results revealed that there was an effect of gender on students' cognitive achievement in Basic Electronics. In the same vein, analysis of covariance was used to test hypothesis three (Table 5) for interaction of treatments and gender revealed that there was no significant interaction effect of treatments given to students and their gender with respect to their mean scores on the Basic Electronics Cognitive Achievement Test. Also, analysis of covariance was used to test hypothesis two, (Table 5). With these results, there was a significant difference between the mean scores of students in Basic Electronics Cognitive Achievement Test when taught using the scaffolding instructional approach and those taught with the collaborative instructional approach, in favour of collaborative instructional approach.

These imply that both scaffolding and collaborative instructional approaches are not gender-biased in teaching of subjects like Basic Electronics. This finding is similar to findings of several other studies that have been conducted on effects of gender on achievement of male and female students in sciences and other fields. For instance, Nwagbo and Obiekwe (2010) affirmed that there was no significant difference between male and female students' achievement. This view was reiterated by Afolabi and Akinbobola (2009) who discovered that there was no significant gender difference in the performance of students taught with a problem-based learning technique in a physics achievement test. Abubakar and Bada (2012), and Ogbuanya and Owodunni (2013) also found that gender is not significant in the academic achievement between females and males. Hence, these findings confirmed that when males and females are exposed to academic activities in subjects like Basic Electronics, under the same environmental conditions, and taught by the same teacher using the same methodology, their performance level would be the same.

\section{CONCLUSION}

The need to find the most appropriate instructional approach to assist Basic Electronics students in their academic activities, stimulate and sustain their interest is very important. This is because interest is a key ingredient for recording high achievement in any academic pursuit and especially in technology education. This study therefore ascertained the comparative effects of scaffolding and collaborative instructional approaches on secondary school students' achievement in Basic Electronics in North-Central Nigeria. The study found out that the collaborative instructional approach is more effective in improving students' cognitive achievement in Basic Electronics than the scaffolding instructional approach. Also, the study revealed that, gender had no influence on students' cognitive achievement in Basic Electronics. The study also revealed that collaborative and scaffolding instructional approaches are not gender-biased. Students recorded higher cognitive in Basic Electronics when the collaborative instructional approach was used for teaching the subject, irrespective of gender. These results therefore show that collaborative instructional approach is a workable teaching method for Basic Electronics. 
The following recommendations are made:

- A collaborative instructional approach is recommended for teachers of electronics and other related trade subjects in secondary schools for use in the teaching of their subjects;

- It is recommended that the Nigerian Educational Research and Development Council (NERDC) should consider incorporating collaborative instructional approaches into the teaching of subjects like Basic Electronics when next they are reviewing the curriculum;

- Government and other stakeholders in the provision of qualitative technology education should do more in providing schools with state-of-the-art tools and equipment needed for the teaching and learning of Basic Electronics; and

- It is recommended that training and retraining workshops, seminars and conferences be organized the National Universities Commission (NUC) along with other sister agencies in collaboration with the Ministries of Education both at federal and states levels, to enlighten teachers of technology education with a view of improving their knowledge with skills on the use of collaborative instructional approaches.

\section{REFERENCES}

Abubakar, R. B., \& Bada, I. A. (2012). Age and gender as determinants of academic achievements in college mathematics. Asian Journal of Natural \& Applied Sciences, 1(20), 121-127.

Abubakar, R. B., \& Oguguo, O. D. (2011). Age and gender as predictors of academic achievement of college mathematics and science students. Journal of Educational and Social Research, 1(2), 89-93.

Afolabi, F., \& Akinbobola, A. O. (2009). Constructivist problem based learning technique and the academic achievement of physics students with low ability level in Nigerian secondary schools. Eurasian Journal of Physics and Chemistry Education, 1(1), 45-51.

Animasahun, R. A. (2014). The menace of examination malpractices in Nigeria secondary schools and remediative measures towards attitudinal re-orientation: The counsellor's perspectives. African Journal for the Psychological Studies of Social Issues, 16(2), 300-309.

Cholewinski, M. (2009). An introduction to constructivism and authentic activity. Journal of the school of contemporary international studies Nagoya University of Foreign Studies, 5, 283-316. Retrieved on 2 December 2017 from https://nufs-

nuas.repo.nii.ac.jp/?action=pages_view_main\&active_action=repository_view_main_item_detail\&item_id =233\&item_no=1\&page_id=13\&block_id=17

Dooly, M. (2008). Constructing knowledge together. Telecollaborative language learning. A guidebook to moderating intercultural collaboration online, 3(1), 21-45.

Elander, K., \& Cronje, J. C. (2016). Paradigms revisited: a quantitative investigation into a model to integrate objectivism and constructivism in instructional design. Educational Technology Research and Development, 64(3), 389-405. https:/ / doi.org/10.1007/s11423-016-9424-y

Ertmer, P. A., \& Newby, T. J. (2013). Behaviorism, cognitivism, constructivism: comparing critical features from an instructional design perspective. Performance Improvement Quarterly, 26(2), 43-71. https:/ / doi.org/10.1002/ piq.21143

Federal Republic of Nigeria, (2013). National policy on education. Lagos. NERDC Press.

Gokhale, A. A. (1995). Collaborative instructional approach enhances critical thinking. Journal of Technology Education, 7(1), 22-30. https:/ / doi.org/10.21061/jte.v7i1.a.2

Gupta, R., Sharma, S., \& Gupta, M. (2012). A study of gender difference on the measure of academic achievement in adolescent students. Visual Soft Research Development Technical and Non-Technical Journal, 3(1), $23-27$.

Harasim, L. (2017). Learning theory and online technologies (second edition). London: Routledge.

Husa, A. A., \& Ron, S. (2010). An analysis and guide for the proposed redesign of the ELS curriculum in Saudi Arabia public school using advanced organizers. Indiana University Bloomington R511 Instructional Technology $\begin{array}{lllllll}\text { Foundations. } & \text { Retrieved } & \text { on } & 30 & \text { November } & 2017 & \text { from }\end{array}$ http://www.husaalangari.com/styles/husa/defiles/Portfolio_ID_Report.pdf

Jabor, M. K., Machtmes, K., Kungu, K., Buntat, Y., \& Nordin, M. S. (2011). The influence of age and gender on the students' achievement in mathematics. International Conference on Social Science and Humanity IPEDR, 5(2011), (pp. 304-308). Singapore.

Jackson, S. R. (2006). Using constructivist methods to teach social studies to special education students. Terminal Masters Project Wayne State University, Detroit, Michigan. 
Jia, Q. (2010). A brief study on the implication of constructivism teaching theory on classroom teaching reform in basic education. International Education Studies, 3(2), 197-199. https:/ / doi.org/10.5539/ies.v3n2p197

Lai-chong, L., \& Ka-ming, W. (1996). Implications and problems of constructivism for instructional design. Education Journal, 23(2), 73-104.

Maliki, A. E., Ngban, A. N., \& Ibu, J. E. (2009). Analysis of students' performance in junior secondary school mathematics examination in Bayelsa State of Nigeria. Kamla-Raj, 3(2), 131-134. https:/ / doi.org/10.1080/09737189.2009.11885288

McNamara, J., \& Brown, C. (2008). Assessment of collaborative learning in online discussions. In ATN Assessment 08: Engaging Students with Assessment. Adelaide: University of South Australia. Retrieved on 15 April 2018 from https:/ / www.ojs.unisa.edu.au/index.php/atna/article/viewFile/214/248/accessed

McNaught, C. (2014). Short paper on the revised Bloom's taxonomy and the Solo taxonomy. Centre for Learning Enhancement And Research (CLEAR), The Chinese University of Hong Kong. Retrieved on 15 April 2018 from http://www.cuhk.edu.hk/clear/download/Learning_at_university.doc

National Examinations Council (NECO). (2010). Chief examiners' report for SSCE June/July 2010. Ilorin: NECO publication.

National Examinations Council (NECO). (2013). Performance of candidates SSCE (June/July) in Electronics 2008-2012. Minna. Statistics Unit, QAD, NECO. Minna: NECO publication.

Nigerian Educational Research and Development Council (NERDC). (2007). Curriculum for basic electronics. Abuja. NERDC press.

Nwagbo, C., \& Obiekwe, C. (2010). Effects of constructivist instructional approach on students' achievement in basic ecological concepts in biology. Journal of Science Teachers Association of Nigeria, 45(1 \& 2), $26-35$.

Nworgu, B. G. (2006). Educational research: basic issues and methodology. Enugu. University trust publishers.

Ofojebe, W. N. (2010). Teachers' Motivation and its influence on quality assurance in the Nigerian educational system. African Research Review, 4(2), 398-417. https:// doi.org/10.4314/afrrev.v4i2.58352

Ogbuanya, T. C., \& Owodunni, A. S. (2013). Effects of reflective inquiry instructional technique on students' achievement and interest in radio television and electronics works in technical colleges. IOSR Journal of Engineering, 3(11), 2250-3021. https:/ / doi.org/10.9790/3021-031120111

Ogundola, I. P., Abiodun, A. P., \& Jonathan, O. O. (2010). Effects of constructivist instructional approach on teaching practical skills to mechanical related trade students in western Nigeria technical colleges. International NGO Journal, 5(3), 59-64.

Okoro, O. M. (1999). Principles and methods in vocational and technical education. Nsukka. University trust publishers.

Reiser, B. J. (2004). Scaffolding complex learning: the mechanisms of structuring and problematizing student work. The Journal of the Learning Sciences, 13(3), 273-304. https:/ / doi.org/10.1207/s15327809j1s1303_2

Rowe, K. (2006). Effective teaching practices for students with and without learning difficulties: Constructivism as a legitimate theory of learning and of teaching. Australian Council for Educational Research, 1-24.

Wu, P. H., Hwang, G. J., Su, L. H., \& Huang, Y. M. (2012). A context-aware mobile learning system for supporting cognitive apprenticeships in nursing skills training. Educational Technology \& Society, 15(1), 223-236.

Wyer Jr, R. S. (Ed.). (2014). The automaticity of everyday life: Advances in social cognition. Advances in Social Cognition Series (Book 10). London: Psychology Press. 


\section{APPENDIX A}

\section{SAMPLE OF BASIC ELECTRONICS COGNITIVE ACHIEVEMENT TEST (BECAT)}

\section{STUDENT BIODATA}

STUDENT'S REGISTRATION NUMBER

NAME OF SCHOOL

\section{GENDER}

1. The electronic configuration of a silicon atom is
A. $2,10,2$.
B. $2,8,4$.
C. $2,7,5$.
D. $2,4,8$.

2. Materials that only allow electricity to pass through them at an increased temperature are called
A. conductors.
B. insulators.
C. resistors.
D. semiconductors.

3. The major part of the current in an intrinsic semiconductor is due to
A. conduction of band electrons.
B. holes in the valence band.
C. thermally-generated electrons.
D. valence-band electrons.

4. Electrons experience high mobility than holes because they
A. are lighter.
B. collide less frequently.
C. have negative charge.
D. need less energy to move them.

\section{[MALE/FEMALE]}

5. Doping materials are called impurities because they
A. alter the crystal structures of the pure semiconductors.
B. change the chemical properties of semiconductors.
C. decrease the number of charge carriers.
D. make semiconductors less than 100 percent.

6. Current flow in a semiconductor depends on the principle of
A. all of THESE.
B. diffusion.
C. drift.
D. recombination.

7. The process of adding impurities to a semiconductor is known as
A. diffusion.
B. doping.
C. mixing.
D. refining.

8. What is the most widely used semiconductor material in electronics?
A. Antimony
B. Carbon.
C. Germanium.
D. Silicon. 


\section{APPENDIX B}

\section{SAMPLE OF SCAFFOLDING INSTRUCTIONAL APPROACH (SIA) LESSON PLAN}

SUBJECT: Basic Electronics

TOPIC: Electrical Conduction Properties of Elements

CLASS: SS II

LESSON DURATION: 80 minutes

DATE:

OBJECTIVES: At the end of the lesson, the students should be able to

1. Explain the electrical conduction properties of elements.

2. Define semiconductors, give examples and write their electronic configuration.

3. Discuss the crystal structure of semiconductors.

4. Explain the classification of semiconductors and show it diagrammatically. INSTRUCTIONAL MATERIALS:

1. Semiconductor devices such as diodes, transistors, SCRs, ICs of different types.

2. Basic Electronics textbook,

3. The periodic table,

4. Chemistry textbook, and

5. Semiconductor questions card sheets. 
PRELUDE: The teacher introduces the topic by making a few comments e.g. Semiconductors are midway between good conductors and insulators. Their uses have become indispensable in today's world.

The teacher then asks the students to place the following materials - Basic Electronics Textbook, Periodic Table and chemistry textbook - on their table.

The teacher asks the students to open their textbooks to the relevant pages.

\begin{tabular}{|c|c|c|c|c|c|c|}
\hline Stage & Duration & Content & Teacher's activities & Students' activities & Scaffold & SIA Strategy \\
\hline 1 & $8 \mathrm{~min}$ & $\begin{array}{l}\text { Electrical } \\
\text { conduction } \\
\text { properties of } \\
\text { elements }\end{array}$ & $\begin{array}{l}\text { The teacher } \\
\text { distributes the } \\
\text { question cards on } \\
\text { electrical conduction } \\
\text { properties of } \\
\text { elements }\end{array}$ & $\begin{array}{l}\text { The students collect the } \\
\text { question cards, search for the } \\
\text { information in their textbooks } \\
\text { and make a list of the properties } \\
\text { in their notebook }\end{array}$ & $\begin{array}{l}\text { Is there anything like } \\
\text { electrical conduction } \\
\text { properties of elements; are } \\
\text { there any classification; how } \\
\text { are the types defined; which } \\
\text { one of them forms the topic } \\
\text { being studied? }\end{array}$ & QUESTION CARD \\
\hline 2 & $12 \min$ & $\begin{array}{l}\text { Semiconductors, } \\
\text { examples, their } \\
\text { electronic } \\
\text { configuration }\end{array}$ & $\begin{array}{l}\text { The teacher passes } \\
\text { some semiconductor } \\
\text { devices such as } \\
\text { diodes, transistors, } \\
\text { SCRs, ICs of different } \\
\text { types to the students } \\
\text { to both see and } \\
\text { touch }\end{array}$ & $\begin{array}{l}\text { Students see and touch the } \\
\text { semiconductor devices such as } \\
\text { diodes, transistors, SCRs, ICs of } \\
\text { different types. Draw and label } \\
\text { them with their circuit symbols. }\end{array}$ & $\begin{array}{l}\text { Give examples of } \\
\text { semiconductors and show } \\
\text { their electronic } \\
\text { configurations }\end{array}$ & $\begin{array}{l}\text { VISUAL } \\
\text { SCAFFOLDS }\end{array}$ \\
\hline
\end{tabular}

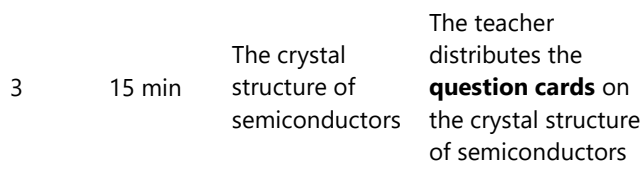

The students collect the question cards, search for the information in their textbooks, make a note and draw crystal structure of semiconductors in their notebook
With the aid of a diagram briefly explain the crystal structure of semiconductors
QUESTION CARDS

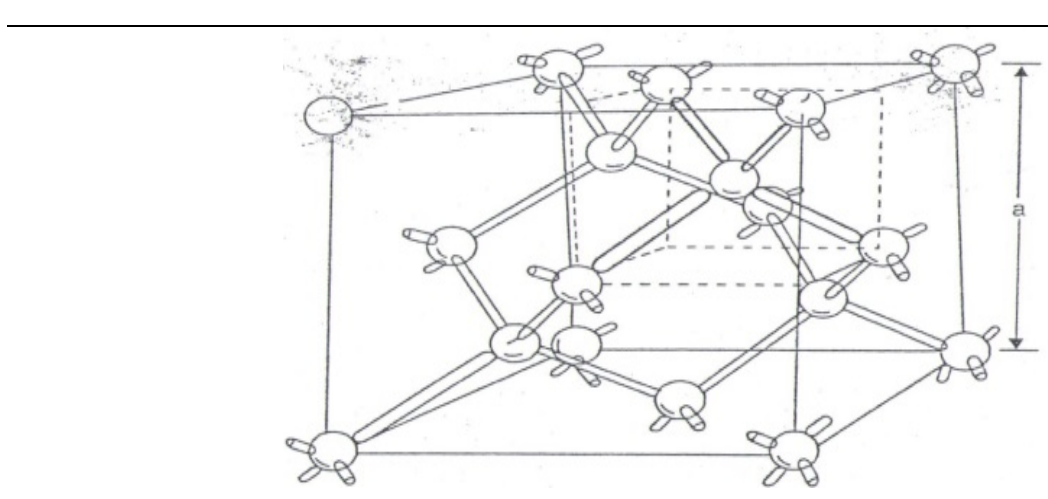

Crystal structure of semiconductors

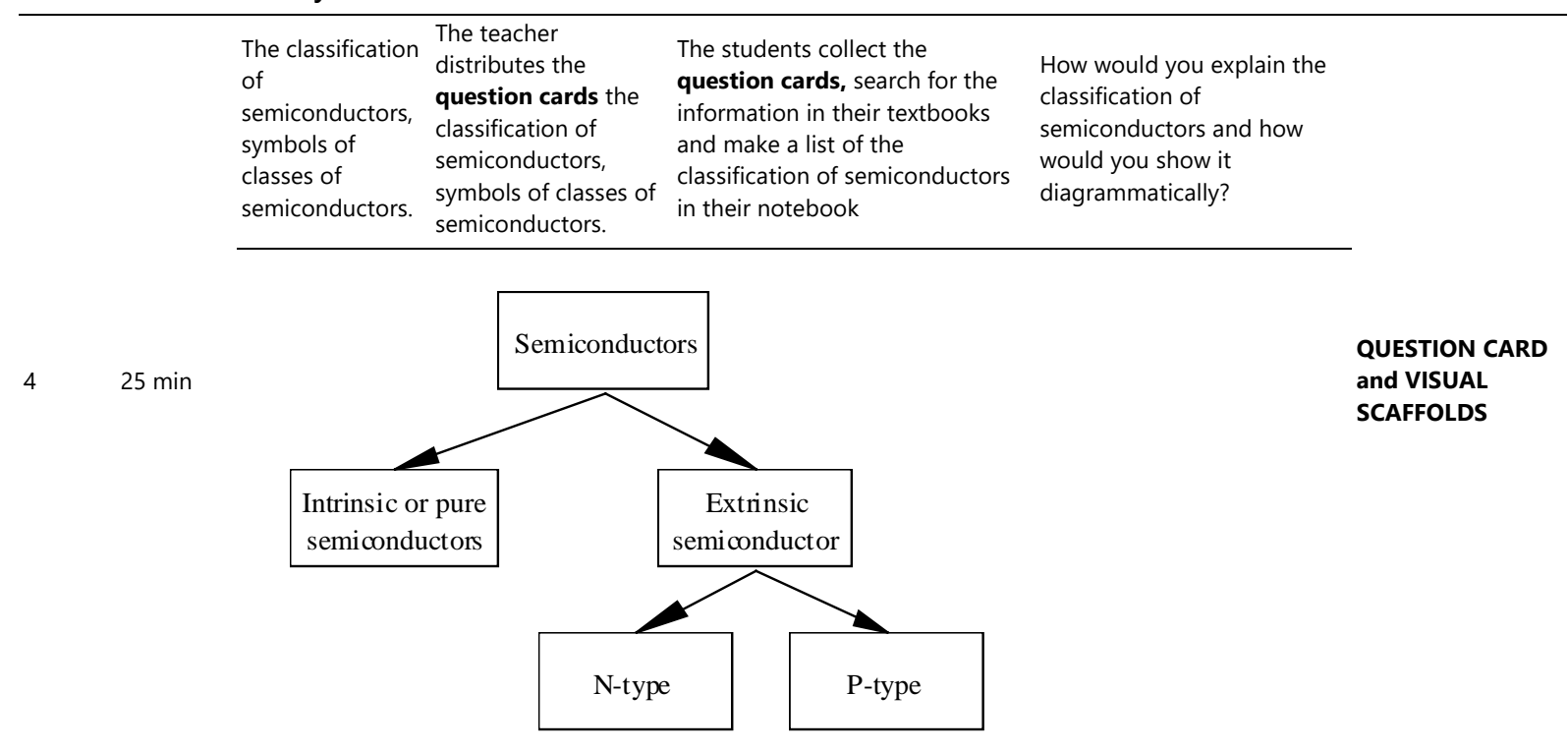


EVALUATION: (For $15 \mathrm{~min}$ )

The teacher randomly call on students to answer the following questions:

1. Explain the electrical conduction properties of elements.

2. Define semiconductors, give examples and write their electronic configuration.

3. Discuss the crystal structure of semiconductors.

4. Explain the classification of semiconductors and show it diagrammatically.

ASSIGNMENT: The teacher instructs the students to make detailed notes on the topic, study them and prepare for a shotgun test next week. 


\section{APPENDIX C}

\section{SAMPLE OF COLLABORATIVE INSTRUCTIONAL APPROACH (CIA) LESSON PLANS}

SUBJECT: Basic Electronics

TOPIC: Electrical Conduction Properties of Elements

CLASS: SS II

LESSON DURATION: 80 minutes

DATE:

OBJECTIVES: At the end of the lesson, the students should be able to

1. Explain the electrical conduction properties of elements.

2. Define semiconductors, give examples and write their electronic configuration.

3. Discuss the crystal structure of semiconductors.

4. Explain the classification of semiconductors and show it diagrammatically.

\section{INSTRUCTIONAL MATERIALS:}

1. Semiconductor devices such as diodes, transistors, SCRs, ICs of different types.

2. Basic Electronics textbook,

3. The periodic table,

4. Chemistry textbook, and

5. Semiconductor questions card sheets. 
PRELUDE: The teacher calls out names of students to constitute their various groups comprising of three students each.

The teacher introduces the topic by making a few comments e.g. Semiconductors are midway between good conductors and insulators. Their uses have become indispensable in today's world.

The teacher then asks the students to place the following materials Basic Electronics Textbook, Periodic Table and chemistry textbook on their table.

The teacher asks the students to open their textbooks to the relevant pages.

\begin{tabular}{|c|c|c|c|c|c|c|}
\hline Stage & Duration & Content & Teacher's activities & Students' activities & Task & CIA Strategy \\
\hline 1 & $8 \mathrm{~min}$ & $\begin{array}{l}\text { Electrical } \\
\text { conduction } \\
\text { properties of } \\
\text { elements }\end{array}$ & $\begin{array}{l}\text { The teacher distributes the } \\
\text { task cards on electrical } \\
\text { conduction properties of } \\
\text { elements to the groups }\end{array}$ & $\begin{array}{l}\text { The groups collect the task } \\
\text { cards, search for the } \\
\text { information in their textbooks } \\
\text { and make a list of the } \\
\text { properties in their notebook }\end{array}$ & $\begin{array}{l}\text { Study about electrical } \\
\text { conduction properties of } \\
\text { elements, state their } \\
\text { classification }\end{array}$ & $\begin{array}{l}\text { THINK-PAIR- } \\
\text { SHARE }\end{array}$ \\
\hline 2 & $12 \mathrm{~min}$ & $\begin{array}{l}\text { Semiconductors, } \\
\text { examples, their } \\
\text { electronic } \\
\text { configuration }\end{array}$ & $\begin{array}{l}\text { The teacher passes some } \\
\text { semiconductor devices such } \\
\text { as diodes, transistors, SCRs, } \\
\text { ICs of different types to each } \\
\text { group for the members to } \\
\text { both see and touch }\end{array}$ & $\begin{array}{l}\text { Group members see and } \\
\text { touch the semiconductor } \\
\text { devices such as diodes, } \\
\text { transistors, SCRs, ICs of } \\
\text { different types }\end{array}$ & $\begin{array}{l}\text { Give examples of } \\
\text { semiconductors and show } \\
\text { their electronic } \\
\text { configurations }\end{array}$ & SIMPLE JIGSAW \\
\hline 3 & $15 \min$ & $\begin{array}{l}\text { The crystal } \\
\text { structure of } \\
\text { semiconductors }\end{array}$ & $\begin{array}{l}\text { The teacher distributes the } \\
\text { task cards on the crystal } \\
\text { structure of semiconductors } \\
\text { to the groups }\end{array}$ & $\begin{array}{l}\text { The groups collect the task } \\
\text { cards, search for the } \\
\text { information in their textbooks, } \\
\text { make a note and draw crystal } \\
\text { structure of semiconductors } \\
\text { in their notebook }\end{array}$ & $\begin{array}{l}\text { With the aid of a diagram } \\
\text { briefly explain the crystal } \\
\text { structure of } \\
\text { semiconductors }\end{array}$ & SIMPLE JIGSAW \\
\hline
\end{tabular}

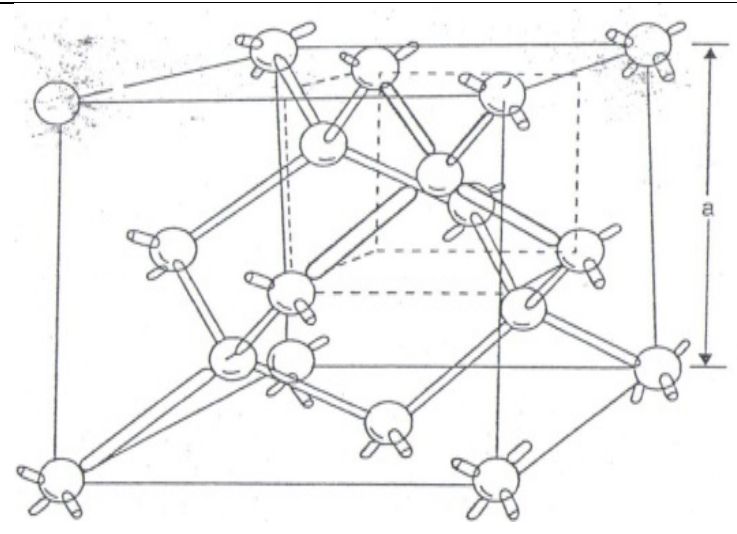

crystal structure of semiconductors

\begin{tabular}{|c|c|c|c|c|c|c|c|}
\hline \multirow{4}{*}{4} & \multirow{4}{*}{$25 \min$} & $\begin{array}{l}\text { The classification of } \\
\text { semiconductors, symbols } \\
\text { classes of semiconductor }\end{array}$ & & $\begin{array}{l}\text { The teacher distributes } \\
\text { the task cards the } \\
\text { classification of } \\
\text { semiconductors, symbols } \\
\text { of classes of } \\
\text { semiconductors to the } \\
\text { groups }\end{array}$ & $\begin{array}{l}\text { The groups collect the } \\
\text { task cards, search for the } \\
\text { information in their } \\
\text { textbooks and make a list } \\
\text { of the classification of } \\
\text { semiconductors in their } \\
\text { notebook }\end{array}$ & $\begin{array}{l}\text { Explain the } \\
\text { classification of } \\
\text { semiconductors and } \\
\text { draw the diagram }\end{array}$ & \multirow{4}{*}{$\begin{array}{l}\text { THINK-PAIR- } \\
\text { SHARE }\end{array}$} \\
\hline & & & \multirow[t]{3}{*}{ Sen } & iconductors & & & \\
\hline & & $\begin{array}{l}\text { Intrinsic or pure } \\
\text { semiconductors }\end{array}$ & & $\begin{array}{c}\text { Extrinsic } \\
\text { semiconductor }\end{array}$ & & & \\
\hline & & & & N-type & P-type & & \\
\hline
\end{tabular}


EVALUATION: (For $13 \mathrm{~min}$ )

The teacher randomly calls on students from groups to answer the following questions:

1. Explain the electrical conduction properties of elements.

2. Define semiconductors, give examples and write their electronic configuration.

3. Discuss the crystal structure of semiconductors.

4. Explain the classification of semiconductors and show it diagrammatically.

ASSIGNMENT: The teacher will instruct the groups to make detailed notes on the topic, study them and prepare for an inter-group quiz next week.

\section{http://www.ejmste.com}

